\title{
Diplomatic Correspondence: \\ A Comparative Study on Malay and Javanese Letters in 1800s
}

\section{Gilang Maulana Majid ${ }^{1}$}

\begin{abstract}
A more established tradition may set an indirect consensus for the communication between rulers in any situation. This article identifies how diplomatic correspondence was conducted and how different perceptions could actually be negotiated to attain certain goals. Two diplomatic letters - one from the Panembahan of Sumenep and one from the Sultan of Yogyakarta dispatched to Thomas Stamford Raffles to address Raffles' retirement during the British interregnum in Java from 1811 to 1816 were analyzed. These letters were chosen due to the different scripts and languages used in the two letters: Classical Malay Jawi and Old Javanese 'aksara Jawa'. By applying content analysis, this study finds that the Malay language was not only influential throughout the Indonesian archipelago as a medium for verbal communication, but its letter-writing tradition even clearly affected its Javanese counterpart, setting a standard writing style for diplomatic letters.
\end{abstract}

Keywords: Diplomatic Correspondence, Javanese Script, Malay Jawi, Raffles, British Interregnum in Java.

${ }^{1}$ Southeast Asian Studies, Goethe University of Frankfurt, Germany. Corresponding e-mail: gilangmm20@gmail.com. 


\section{Gilang Maulana Majid}

\section{Introduction}

Although Malay served as the lingua franca of the archipelago that would later be called 'Indonesia' after its independence in 1945, at some point it was deemed offensively coarse and uncultured by the aristocratic Javanese. ${ }^{2}$ In letter writing, most Javanese rulers, particularly in the interior, used the Javanese script instead of "the Malay Jawi (Perso-Arabic) script that has been the medium of international and inter-island mode of communication between Indonesian rulers and foreign monarchs, merchants, and officials" for over four hundred years (Jones, 1982, pp. 14-15, in Gallop \& Arps, 1991, p. 33). The mix of these two types of script is probably best represented in the 'Raffles Papers', a collection of complimentary addresses sent to Thomas Stamford Raffles by the native rulers of Java on his retirement in $1816 .^{3}$ For instance, while the letters from Sultan Anom and Sultan Sepuh of Cirebon are written in Jawi, ${ }^{4}$ the letters from the regents of Bandung, Garut, and Sumedang use the Javanese script. This demonstrates how varied ${ }^{5}$ the language used by the rulers of Java was as a medium of communication.

As a case in point, some of the letters in this collection are illuminated, referring to the inclusion of a frontispiece framing the manuscript text. When one is delving into Malay letter-writing, then

\footnotetext{
${ }^{2}$ See Hannigan (2011, p. 13). This impression was recorded when Raffles first visited the court of Yogyakarta and addressed the court in Malay instead of following the approach of the earlier Dutchmen, who had learnt to speak high, formal Javanese when communicating with Javanese kings. Also, see Purwadi (2008) to understand the creativity of the Javanese people in using their traditional language and playing with the aesthetics of the Javanese script, such as through traditional songs.

${ }^{3}$ See British Library Add. 45237 http://www.bl.uk/manuscripts/FullDisplay. aspx?ref=Add_MS_45273\&index=9

${ }^{4}$ When one looks at the script used by the courts of coastal trading ports in the collection, they are usually written in Jawi instead of the Javanese script. This, to some extent, echoes the inference made by Behrend, as these are also the areas that were first affected by the changes in material culture that were caused by the rise of Islam (2005, p. 43).

${ }^{5}$ Another analysis exemplifying the complexity of the language used by Javanese courts is presented by Pudjiastuti (2005). It encompasses a descriptive account of Pegon, i.e. the Arabic script used to write Javanese. The type of Pegon script used-gundhul or sandangan - was also determined by the status of the addressee (p. 128).
} 
its manual-the kitab terasul, which contain guidelines for the proper composition of letters-should automatically be involved. One such kitab terasul was compiled by M. Abdul Nasir (Gallop, 2010, p. 184), and outlines how to create designs and decorations, write complimentary addresses, headings, where to place the seal, and so forth (Gallop, 1994). Unfortunately, no equivalent guidelines have been found in the Javanese letter-writing tradition; there is only a discussion of wadana, of Javanese manuscript illuminations, by Tim Behrend ${ }^{6}$ (2005, p. 46). It is interesting, thus, to explore the Javanese letter-writing practice in previous centuries. Was there any influence from the Malay letterwriting practice? If yes, to what extent did Javanese letters follow the common rules of Malay letter-writing?

This study attempts to answer the above questions by comparing two letters written in these two different scripts: a letter from the Panembahan of Sumenep written in Malay Jawi and a letter from the Sultan of Yogyakarta written in Aksara Jawa (Javanese script). These two letters were sent ${ }^{7}$ to Thomas Stamford Raffles, the Lieutenant-Governor during the British Interregnum in Java (1811-1816), on the occasion of his retirement following the return of the island's administration to the Dutch. ${ }^{8}$ The letters from the Panembahan of Sumenep and the Sultan of Yogyakarta were chosen due to the special relationship they had with the British rulers during this short period of time.

Necessarily, this begs the question of what kind of relationship was built between these native rulers and the British, and who were the prominent figures within that took part into building such relations. In this article, these questions are answered by first providing a historical

\footnotetext{
${ }^{6}$ Behrend writes that aspects such as page layout, orthographics, calligraphic embellishment, and illumination, despite their importance in Javanese chirography, "have been almost entirely ignored in the nearly two centuries of scholarship dedicated to the literary and material cultures of the region" (2005, p. 40).

${ }^{7}$ Such letters were usually delivered by an ambassador before reaching the addressee. One example of such activity is mentioned by Ricklefs (1993, p. 115)

${ }^{8}$ Following the terms of the Anglo-Dutch convention of August 13, 1814 (Wurtzburg, 1986, p. 378).
} 


\section{Gilang Maulana Majid}

account of the interactions - before the British interregnum - between the kingdoms of Madura, where the Panembahan of Sumenep was located, and Central Java, where power was centered in Java before the Yogyakarta court came into being. The political situation in these two courts - Sumenep and Yogyakarta - during the era of British interregnum will then be covered, with discussion including the key figures who influenced the development of special relationship developed. Only then will this article present a comparative study of the two aforementioned letters. The final section will present concluding remarks.

\section{Historical Account}

\section{Kingdoms in Madura and Central Java Before the British Interregnum}

There are at least two major events designating the involvement of Madura in the political sphere of the kingdoms of Central Java, namely the cession of East Madura to the Dutch East India Company (VOC) in 1705 and the cession of West Madura in 1743 (Ricklefs, 2008, p. 162). After the expansion of Mataram Kingdom's territorial power to Madura in $1624,{ }^{9}$ under the reign of Sultan Agung, the island was never able to shed the control of Java's ruling powers. ${ }^{10}$ Between 1624 to 1705, two major events occurred that ultimately led to the cession of East Madura to the VOC: the Trunajaya Rebellion and the First Javanese War of Succession. In October 1705, Pakubuwana I and the VOC agreed on a new contract regarding the erasure of the dynasty's accumulated debts, which had been caused by its financial losses in wars before 1705. Under this contract, the eastern half of Madura was to be ceded to the VOC (Ricklefs, 2008, p. 105). This agreement was pursuant to the wishes of Tumenggung Yudanegara (d. 1684), the former ruler of Sumenep, who

${ }^{9}$ See de Graaf (2002, pp. 101-114) for more detail on the conquest of Madura by Sultan Agung.

${ }^{10}$ Many prisoners of war from Madura were taken to Central Java and employed as forced laborers, who received low wages for working agricultural lands (De Graaf \& Pigeaud, 1985, p.220). 
had asserted that he would rather be a VOC vassal than be under the authority of the Mataram Kingdom. ${ }^{11}$

Madurese intervention in Java continued until the cession of West Madura to the VOC in 1743. In June-July 1741, Cakraningrat IV decided to ally with the VOC in the fight against Pakubuwana II, the ruler of the Kartasura court, ${ }^{12}$ after being promised freedom from Kartasura's control and the independent administration of East Java, under VOC protection (Ricklefs, 2008, p. 115). In November 1742, Kartasura was conquered by Cakraningrat IV's forces. The following year, a treaty was signed that, among other things, fully ceded sovereignty over West Madura and coastal northeastern Java to the VOC (Ricklefs, 2008, 116). Important to note is that, before the British interregnum, a treaty separating Central Java into three influential courts - Mangkunegaran, ${ }^{13}$ the Kasunanan of Surakarta, and the Kasultanan of Yogyakarta - was already in place; a fourth court, Pakualaman, would later be created in 1812.

\section{The Courts of Yogyakarta and Sumenep during the British Interregnum}

The British presence in Java marked the completion of the division of Mataram kingdom into two senior (Kasultanan of Yogyakarta and Kasunanan of Surakarta) and two junior (Mangkunegaran and Pakualaman) principalities. The initial situation before the British arrival in 1811 was that Natakusuma, the Sultan's brother and an enemy of Governor-General Herman Willem Daendels. ${ }^{14}$ was exiled

\footnotetext{
${ }^{11}$ See Rahayu (2016) for the details of the factors that made Sumenep willing to become the first vassal state of the VOC.

${ }^{12}$ The Mataram Kingdom no longer existed after its capital, Plered, was destroyed by Trunajaya and occupied by Pangeran Puger, the future Pakubuwana I. In response, Amangkurat II moved the capital of the court in Central Java to Kartasura - an area that today lies between Yogyakarta and Surakarta - to collect his forces before attacking Plered (Ricklefs, 2008, p. 94).

${ }^{13}$ Mangkunegaran had his own domain in Surakarta and is often referred as its junior court (Ricklefs, 2008, p. 121)

${ }^{14} \mathrm{He}$ was the Governor-General of the Dutch East Indies sent by the Napoleonic regime in 1808 to fortify Java as a base against the British in the Indian Ocean (Ricklefs, 2008,
} 


\section{Gilang Maulana Majid}

to imprisonment in Cirebon. Meanwhile, Sultan Hamengkubuwana II was dethroned ${ }^{15}$ and replaced by his son, Sultan Hamengkubuwana III. When the British came, Sultan Hamengkubuwana II seized this opportunity to retake the throne and reduce Sultan Hamengkubuwana III's status to crown prince (Ricklefs, 2008, p. 137). However, Sultan Hamengkubuwana II was hostile towards the new colonial power (Kresna, 2011, p. 218), and he soon resisted British rule. The British, thus, brought Natakusuma back from exile and allied with him against the Sultan and his son. With Natakusuma's assistance, the British successfully conquered the Yogyakarta court in 1812, and in return for his service Natakusuma was rewarded with the title Pangeran Pakualam I and an independent inheritable domain of 4,000 households and land in Yogyakarta (Ricklefs, 2008, p. 138). Meanwhile, Hamengkubuwana II was exiled to Penang and replaced by Hamengkubuwana III, who died two years later and was replaced by his son, Hamengkubuwana IV. Pakualam I was named the guardian of the young Sultan, then only ten years old, and held this position - believed to be part of his reward for his previous assistance - until 1820 (Dwiyanto, 2009, p. 235). Not only did Pakualam I help Raffles promote English policies at the Yogyakarta court (Neil, 2009, p. 236), but he also managed to establish good relations with other British rulers by helping them deal with literary sources, some of which would be used for Raffles' book The History of Java. ${ }^{16}$

Another native ruler known for his friendships with the British rulers, which were again based on literary and scholarly interest, was the Panembahan of Sumenep. Known as "an erudite and learned man who was evidently on good terms with Raffles", the Panembahan governed Sumenep from 1811 to 1854 . He helped Raffles translate ancient steles

p. 135). The Dutch East Indies was basically a nationalized VOC, which had been dissolved in 1800 due to bankruptcy.

${ }^{15}$ He was dethroned because he was accused of being responsible for Raden Rangga's rebellion against the Dutch in 1810 (Ricklefs, 2008, p. 136)

${ }^{16}$ This was published after Raffles returned to England in 1817 and was knighted (Gallop, 1994, p. 143). 
into Malay and provided him with information on several Kawi words (Gallop \& Arps, 1991, p. 78). For this, he received an honorary doctorate degree in the field of literature from the Government of the United Kingdom (Hernawan, 2016, p. 250). However, little information on the political situation of the Panembahan of Sumenep during the British interregnum is available, as his court was not as influential as the courts in Central Java (Marihandono \& Juwono, 2008, p. 137).

\section{Case Study: Comparing a Letter From the Panembahan of Sumenep and a Letter From Kraton Yogyakarta}

This paper addresses two letters with different scripts and languages, examining the degree of similarity and difference between them in the following sections. Since the Malay letter had a terasul guiding its writing, important remarks are made on how the Javanese letter attempts to follow existing rules.

\section{General Condition of The Letters}

Both letters can be found in 'Add MS 45273' (the 'Raffles Papers') in the catalogue of the British Library and are dated 1816. The 'Raffles Papers' mostly consist of complimentary addresses sent to Raffles by the people of Java on his retirement as a Lieutenant-Governor in 1816. The papers are classified into four different categories, based on their senders; both letters examined herein fall into the third category, 'addresses from native rulers in Javanese and Malay'. A total of 44 letters are included in this group, all of which are dated between March and May 1816. These letters use various scripts, including Javanese, Jawi, and Romanized Malay, and most include seals. Of these, only one is illuminated: that of the Panembahan of Sumenep. On the upper part of each sheet is written the name of the sender, i.e. "From His Highness the Sultan of Djocjo Carta" for the letter from the Sultan and "From the Panembahan of Sumenep" for the letter from the Panembahan of Sumenep. While, according to Gallop, the letter from the Panembahan of Sumenep was written on May 1,1816, in the common year $(1991,138)$, 


\section{Gilang Maulana Majid}

the Javanese letter does not provide any information in common year; it only includes the date 9 Jumadilawal 1743, using the Javanese calendar.

\section{Formal Characteristics \\ Design and Decoration}

The studied letters differ in the number of sheets used to write them. While the letter from the Sultan of Yogyakarta is written on two sheets of paper, the one from the Panembahan of Sumenep seems to use only one sheet of paper, which - when unfolded - is apparently of the same size as the two sheets combined horizontally. The letter from the Panembahan of Sumenep is beautifully illuminated with floral motifs and gold ${ }^{17}$ ornaments, which Gallop describes as having been influenced by European artistic style and manifesting "the naturalistic depictions of flowers and the vibrant use of color" (1994, p. 41). In contrast, the letter from the Sultan of Yogyakarta is not illuminated, showing that any illumination in a letter - not mentioned in any terasul - would depend on its original purpose (Gallop, 1994, p. 37). Hence, it is concluded that the Panembahan of Sumenep, considering the tone and content of the letter, may have intended to display the close relationship he had with Raffles, as justified by his meaningful contribution in Raffles' The History of Java. On the other hand, though Pakualam I was also on good terms with the British rulers and contributed some insightful insider archives, he was only the patih (guardian) of the Sultan of Yogyakarta. Last, both letters end with the date and place of writing.

\section{Seals}

Since Malay letters were generally written by professional scribes and not the senders themselves, to denote their authenticity, seals were put on the letters instead of signatures (as common today). ${ }^{18}$ In the terasul by $\mathrm{M}$. Abdul Nasir, it is stated that if the letter was 'from a raja to a raja or from a raja to anyone else', then it should be positioned at the end of the text

\footnotetext{
${ }^{17}$ The color gold has connotations of majesty and greatness (Gallop, 1994, p. 37)

${ }^{18}$ Gallop (1994, p. 45)
} 
block, on the right side. The seal should be placed at the top of the text, in the center, when the letter is 'from a menteri to a menteri' or 'from a menteri to anyone else', while when it is 'from a commoner to a commoner' or 'from a commoner to anyone else' is should be placed at the bottom of the text, on the left side (Gallop, 1994, pp. 52-53). This guideline is followed by the letter from the Panembahan of Sumenep, on which the seal is positioned in the right-hand margin. The letter from the Sultan of Yogyakarta, however, differs; the seal is placed at the top-left of the page. A similar tendency is exhibited by the letter from the Susuhunan of Surakarta, which was also written to Raffles on the occasion of his retirement (see Figure 1). Therefore, these Javanese letters follow different rules. Although "seal position could determine the relative status of the sender and recipient" (Gallop, 1994, p. 49), the Javanese position the seal on the opposite side expected for someone of such rank. Neither the Sultan nor the Susuhunan can be considered commoners, and they were basically of equal rank with Raffles. Instead, it may be theorized that the seal's position depends on the direction of the script. Arabic/Jawi is written from the right-hand side to the left, while the Javanese script is written like Latin, i.e. from left to right. It is thus the direction in which the script is written that matters, rather than the position of the seal itself.

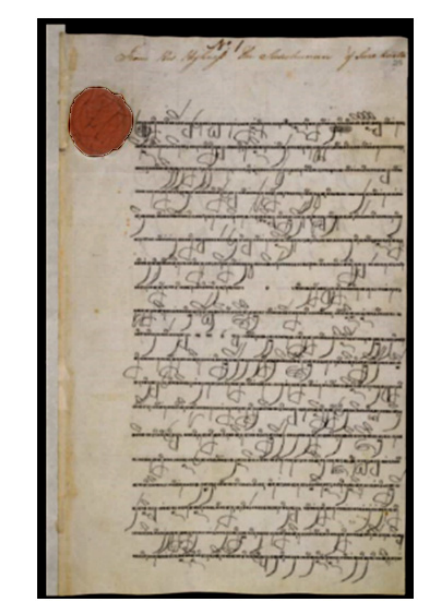

Figure 1. The Letter from the Susuhunan of Surakarta (Source: British Library) 


\section{Gilang Maulana Majid}

Regarding seal color, Gallop wrote that the use of red or maroon wax is "a sign of European influence and was particularly prevalent in the vicinity of Java, including Banten, Madura, and Bali" (1994, p. 49). This is in line with the findings presented in Table 1, since both letters employ these colors. As a source of reference, the seal of an 1815 letter to Raffles from the Sultan of Yogyakarta is shown due to the unavailability of the 1816 letter's inscription. The Javanese script on the seal is difficult to read, as the embossed inscription is unclear. Though the wax colors are different - the seal on the 1815 letter is red, while the one on the 1816 is maroon - this research assumes that, because the Yogyakarta Court had the same ruler between 1814 and 1816, the same seal inscriptions were used. However, this issue still needs further scrutiny. Both the seal of the Sultan of Yogyakarta and the seal of the Panembahan of Sumenep include the same features, including information about the sender's title. However, neither seal contains a personal name, date, place, or religious expression, all of which are usually in such seals. ${ }^{19}$ The seal from the Yogyakarta Court only refers to Sultan Hamengkubuwana, not specifically mentioning the personal name of the fourth sultan, while the seal from the Panembahan of Sumenep does not include the king's personal name.

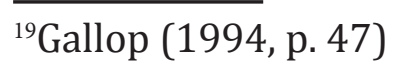


Table 1. Two Seals from Keraton Yogyakarta and One from the Panembahan of Sumenep

\begin{tabular}{|c|c|c|c|}
\hline Sender & Image & Seal Inscription & Further Explanation \\
\hline $\begin{array}{l}\text { Sultan of } \\
\text { Yogyakarta } \\
\text { (1815) }\end{array}$ & & $\begin{array}{l}\text { Kangjeng Sultan } \\
\text { Hamengku } \\
\text { Buwana Senapati } \\
\text { in Ngalaga } \\
\text { Ngabdurrahman } \\
\text { Sayidin } \\
\text { Panatagama } \\
\text { Kalifatullah }^{20}\end{array}$ & $\begin{array}{l}\text { A letter from Sultan } \\
\text { Hamengku Buwana IV } \\
\text { of Yogyakarta to T. S. } \\
\text { Raffles, } 26 \text { Ramelan } \\
\text { A. J. 1742 (September } \\
\text { 1, 1815). Javanese } \\
\text { language and script; } \\
\text { ink on English paper } \\
\text { 'J Whatman 1811'; } \\
\text { red wax seal; } 2 \mathrm{f} \text { (one } \\
\text { blank); 32.4 x 19.5 cm. } \\
\text { Acquired 19788. RV } \\
\text { (1982: 307-8). } \\
\text { British Library, IOL MSS } \\
\text { Eur. E. 378/6, f1r }\end{array}$ \\
\hline $\begin{array}{l}\text { Sultan of } \\
\text { Yogyakarta } \\
\text { (1816) }\end{array}$ & & $\begin{array}{l}\text { No information } \\
\text { available }\end{array}$ & $\begin{array}{l}\text { A letter from Sultan } \\
\text { Hamengku Buwana } \\
\text { IV to T. S. Raffles, on } \\
9 \text { Jumadilawal 1743; } \\
\text { Javanese language and } \\
\text { script; maroon wax seal. } \\
\text { British Library Add } \\
\text { 45273, f.26v-f.27r }\end{array}$ \\
\hline $\begin{array}{l}\text { Panembahan } \\
\text { of Sumenep }\end{array}$ & & $\begin{array}{l}\text { Alamat } \\
\text { Penembahan } \\
\text { Nata Kusuma } \\
\text { al-mazkur balad } \\
\text { Sumenep }\end{array}$ & $\begin{array}{l}\text { Letter from } \\
\text { Panembahan Nata } \\
\text { Kusuma of Sumenep, } \\
\text { Madura, to T. S. Raffles, } \\
3 \text { Jumadilakhir } 1231 \\
\text { (May 1, 1816). Malay } \\
\text { in Jawi script; ink, } \\
\text { polychrome watercolors } \\
\text { and gold on English } \\
\text { paper, 'Stroud \& Co } \\
\text { 1806'; red wax seal; } \\
\text { 46.5 x } 37 \text { cm. From Mrs. } \\
\text { Drake, 1939. RV (1977: } \\
\text { 44). British Library, } \\
\text { Add. 45273, f28v-29r }\end{array}$ \\
\hline
\end{tabular}

(Source: Author's Compilation)

$\overline{{ }^{20} \text { Gallop and Arps }}$ (1991, p. 141) 


\section{Gilang Maulana Majid}

\section{Headings}

According to R. J. Wilkinson, ${ }^{21}$ the positioning of the heading on a letter could have several implications. If it was written in the center, it signified that the writer and the addressee had equal rank. If the heading was situated slightly to the left, the writer was an inferior addressing a superior, while if the heading was placed at the right side of the page the writer claimed a higher position than the addressee (1913, in Gallop \& Arps, 1991, p. 57). ${ }^{22}$ In the letter from the Panembahan of Sumenep, the heading is written "Ya Qadi al-Hajat", which could be translated as "O Fulfiller of Needs" 23 and is located on the center of the page; this indicates that both the sender, the Panembahan of Sumenep, and the recipient, Raffles, were of equal rank. Meanwhile, the letter from the Sultan of Yogyakarta does not have any heading, and instead opens directly with compliments.

\section{The Compliments}

The most distinct character of formal Malay letters is the opening lines, which the terasul refer to as puji-pujian or opening 'compliments'. This contains the names, titles, and addresses of the sender and the recipient, followed by often flowery compliments that expressed through metaphors and similes (Gallop, 1994, p. 63). The letter from the Sultan of Yogyakarta, though written in Javanese, follows the common rules of Malay letters, with its first paragraph containing the aforementioned compliments. The letter from the Panembahan of Sumenep also embodies the same information. The details of these letters' opening compliments are, nonetheless, slightly different, as can be seen in the table below.

\footnotetext{
${ }^{21}$ Also, in the terasul written by M. Abdul Nasir (Gallop, 1994, p. 57)

${ }^{22}$ However, these rules cannot be generalized to all Malay letters, as the headings of several letters are found precisely above the text block but not actually in a central position. See Gallop (1994, p. 61)

${ }^{23}$ See Gallop (1994, p. 60). In Malay, it is translated "Hai yang Menimbangkan segala Maksud".
} 
Table 2. Names, Titles, and Addresses of the Sender and Recipient

\begin{tabular}{|c|c|c|c|}
\hline Sender & Element & Wording & English Translation \\
\hline \multirow[t]{2}{*}{$\begin{array}{l}\text { Sultan of } \\
\text { Yogyakarta }\end{array}$} & $\begin{array}{l}\text { Name, } \\
\text { Title, } \\
\text { Address of } \\
\text { the Sender }\end{array}$ & $\begin{array}{l}\text { kanjeng Sultan Hamengku } \\
\text { Buwana Seenapati } \\
\text { Ingalaga Ngabdurrahman } \\
\text { Sayidin Panatagama } \\
\text { Khalifatollah, ingkang } \\
\text { kaping sekawan, ingkang } \\
\text { anglenggani kedhaton } \\
\text { negari ing Ngayogyakarta } \\
\text { Hadiningrat }\end{array}$ & $\begin{array}{l}\text { His Excellency Sultan } \\
\text { Hamengku Buwana } \\
\text { Senapati Ingalaga } \\
\text { Ngabdurrahman Sayidin } \\
\text { Panatagama Khalifatollah } \\
\text { the fourth, who reigns } \\
\text { over the court of } \\
\text { Yogyakarta Hadiningrat }\end{array}$ \\
\hline & $\begin{array}{l}\text { Name, } \\
\text { Title, } \\
\text { Address } \\
\text { of the } \\
\text { Recipient }\end{array}$ & $\begin{array}{l}\text { ingkang Eeyang kangjeng } \\
\text { tuwan ingkang ageng } \\
\text { ingkang wiceksana, Tomas } \\
\text { Tanporet Raples, Letnan- } \\
\text { Gupenur ing pulo Jawi } \\
\text { sabawahipun sadaya, } \\
\text { ingkang anguwasani } \\
\text { wadya-bala sarta } \\
\text { prajurit Inggris, ingkang } \\
\text { wonten ing tanah Jawi } \\
\text { sabawahipun sadaya }\end{array}$ & $\begin{array}{l}\text { His Excellency, the great } \\
\text { and wise Sir Thomas } \\
\text { Stamford Raffles, } \\
\text { Lieutenant-Governor of } \\
\text { Java Island and the rest, } \\
\text { who controls all British } \\
\text { allies and troops in Java }\end{array}$ \\
\hline \multirow[t]{2}{*}{$\begin{array}{l}\text { Panembahan } \\
\text { of Sumenep }\end{array}$} & $\begin{array}{l}\text { Name, } \\
\text { Title, } \\
\text { Address of } \\
\text { the Sender }\end{array}$ & $\begin{array}{l}\text { Panembahan Nata } \\
\text { Kusuma yang di atas } \\
\text { takhta kerajaan negeri } \\
\text { Sumeneb }\end{array}$ & $\begin{array}{l}\text { Panembahan Nata } \\
\text { Kusuma who reigns over } \\
\text { the court of Sumenep }\end{array}$ \\
\hline & $\begin{array}{l}\text { Name, } \\
\text { Title, } \\
\text { Address } \\
\text { of the } \\
\text { Recipient }\end{array}$ & $\begin{array}{l}\text { Seri Paduka Honarabel } \\
\text { Thomas Stamford Raffles } \\
\text { yang ada bernaung di } \\
\text { bawah takhta kerajaan } \\
\text { maha besar negeri } \\
\text { Ingglan, yang ia mukim } \\
\text { lagi beristirahat al-khair } \\
\text { di dalam negeri Ingglan }\end{array}$ & $\begin{array}{l}\text { His Excellency, the } \\
\text { Honorable Thomas } \\
\text { Stamford Raffles, who } \\
\text { resides under the rule } \\
\text { of the Great Kingdom of } \\
\text { England and rests well in } \\
\text { England }\end{array}$ \\
\hline
\end{tabular}

(Source: Author's Compilation)

While the elements conveying information about the sender of each letter look similar, the emphasis provided in the details about the recipient differ. The letter from the Sultan of Yogyakarta mentions Raffles' presence in Java together with his troops, while the letter from the Panembahan of Sumenep emphasizes England as the country where Raffles would spend his time resting, as further explained in the body/ 


\section{Gilang Maulana Majid}

content of the letter. Below are several examples of the compliments used in the letters. This table shows how the Javanese model attempted to follow the formal aspects of Malay missives.

Table 3. Opening and Closing Lines of the First Paragraph

\begin{tabular}{|c|c|c|}
\hline Sender & Wording & English Translation \\
\hline $\begin{array}{l}\text { Sultan of } \\
\text { Yogyakarta }\end{array}$ & $\begin{array}{l}\text { Punika ingkang serat, pratondha } \\
\text { tulus-iklas kawiyos ing manah } \\
\text { suci ening remen ingkang temen- } \\
\text { temen apawong-sanak, sarta } \\
\text { ingkang tabee akathah-kathah } \\
\text { pinaossenna ingkang ingkang } \\
\text { yusya salametsaha karahharjanne, } \\
\text { denten ing dalem onya puniki }\end{array}$ & $\begin{array}{l}\text { This letter is a sign of sincerity } \\
\text { issued from a pure and loving } \\
\text { heart that is friendly with infinite } \\
\text { salutations } \\
\text { Wish (you) a long and prosperous } \\
\text { life in this world }\end{array}$ \\
\hline $\begin{array}{l}\text { Panembahan } \\
\text { of Sumenep }\end{array}$ & $\begin{array}{l}\text { Bahwa ini warkatikhlas wa tuhfat } \\
\text { al-ajnas yang terbit dari pada } \\
\text { fuwad al-nur kita termaktub di } \\
\text { dalamnya beberapa tabik dan } \\
\text { hormatyang tiada berhingga } \\
\text { Maka dipohonkan pula atasnya } \\
\text { beberapa kebajikan serta mintak } \\
\text { dilanjutkan dari pada usyia umur } \\
\text { zamannya ali al-dawam }\end{array}$ & $\begin{array}{l}\text { This sincere letteris a masterpiece } \\
\text { issued from a heart that is full } \\
\text { of light and contains within it } \\
\text { infinite salutations and respect } \\
\text { Wish (you) some virtue and a } \\
\text { long life }\end{array}$ \\
\hline
\end{tabular}

(Source: Author's Compilation)

From the table above, it can be seen that, although both letters differ in the language used for communication, the very first and last lines of their first paragraphs convey highly similar messages. The Javanese letter even adapts the Malay word 'tabik' as 'tabé', with the same meaning. ${ }^{24}$ It is important to note, however, that the letter from the Panembahan of Sumenep contains more flowery phrases such as "selagi bumi langit keterangan dari pada cahaya peridaran cakrawala alsyams wa al-qamar"25 and "Tuhan seru sekalian alam datang mengadap

\footnotetext{
${ }^{24}$ Based on its lack of inclusion in the 'Jawa - Indonesia'section of the three dictionaries consulted - Mangunsuwito (2002a, 2002b) and Sudarmanto (2008) - the word is uncommon in Javanese.

${ }^{25}$ This can be roughly translated as "while the earth and sky are bright as the orbital light of the firmament, the sun, and the moon."
} 
ke hadapan majlis sahabat kita yang dipermulia"26. Such phrases do not appear in the Javanese letter.

\section{Contents}

Connecting phrases come right after the compliments, marking the starting point of the letters main subject. In the letter from the Panembahan of Sumenep, "Wa-badahu kemudian dari pada itu", a standard connecting phrase in Malay letters meaning "after that",27 is used. In the same fashion, the letter from Sultan of Yogyakarta incorporates the same phrase, but only in Javanese, without any Arabic element. The opening phrase "Sasampuning kadya punika awiyos", equivalent to "setelah demikian" in Indonesian and "after that" in English, can be found after a long empty space within the letter that signals the opening of a new paragraph. ${ }^{28}$

The letters do not only have the same manner and structure in their compliments and connecting phrases, but are also similar in the subjects they discuss. Below are some excerpts that denote the main topics that are addressed in both letters.

Table 4. Excerpts from Both Letters

\begin{tabular}{llll}
\hline \multicolumn{1}{c}{ Sender } & \multicolumn{1}{c}{ Wording } & English Translation & $\begin{array}{c}\text { Position } \\
\text { in the } \\
\text { letter }\end{array}$ \\
\hline $\begin{array}{l}\text { Sultan of } \\
\text { Yogyakarta }\end{array}$ & $\begin{array}{l}\text { sareh ning kangjeng tuwan } \\
\text { Litnan Gupenur, asangnget } \\
\text { gerahipun, aying akedhah } \\
\text { angngupadhos panggennan } \\
\text { ingkang sae payupang yen } \\
\text { nan ingkang kenging kadamel } \\
\text { tetirah }\end{array}$ & $\begin{array}{l}\text { Sir Lieutenant-Governor, } \\
\text { may you be patient and Paragraph } \\
\text { find a good place so that }\end{array}$ \\
\hline
\end{tabular}

\footnotetext{
${ }^{26}$ This can be roughly translated as "God hails all the universe to come before the house of our honored friend".

${ }^{27}$ Both 'wa-badahu' and 'kemudian dari pada itu' have the same meaning, making the use of both in a single sentence redundant. However, that was common in contemporary writing (Gallop, 1994, p. 71).

${ }^{28}$ See Figure 2 in Attachment 1.
} 


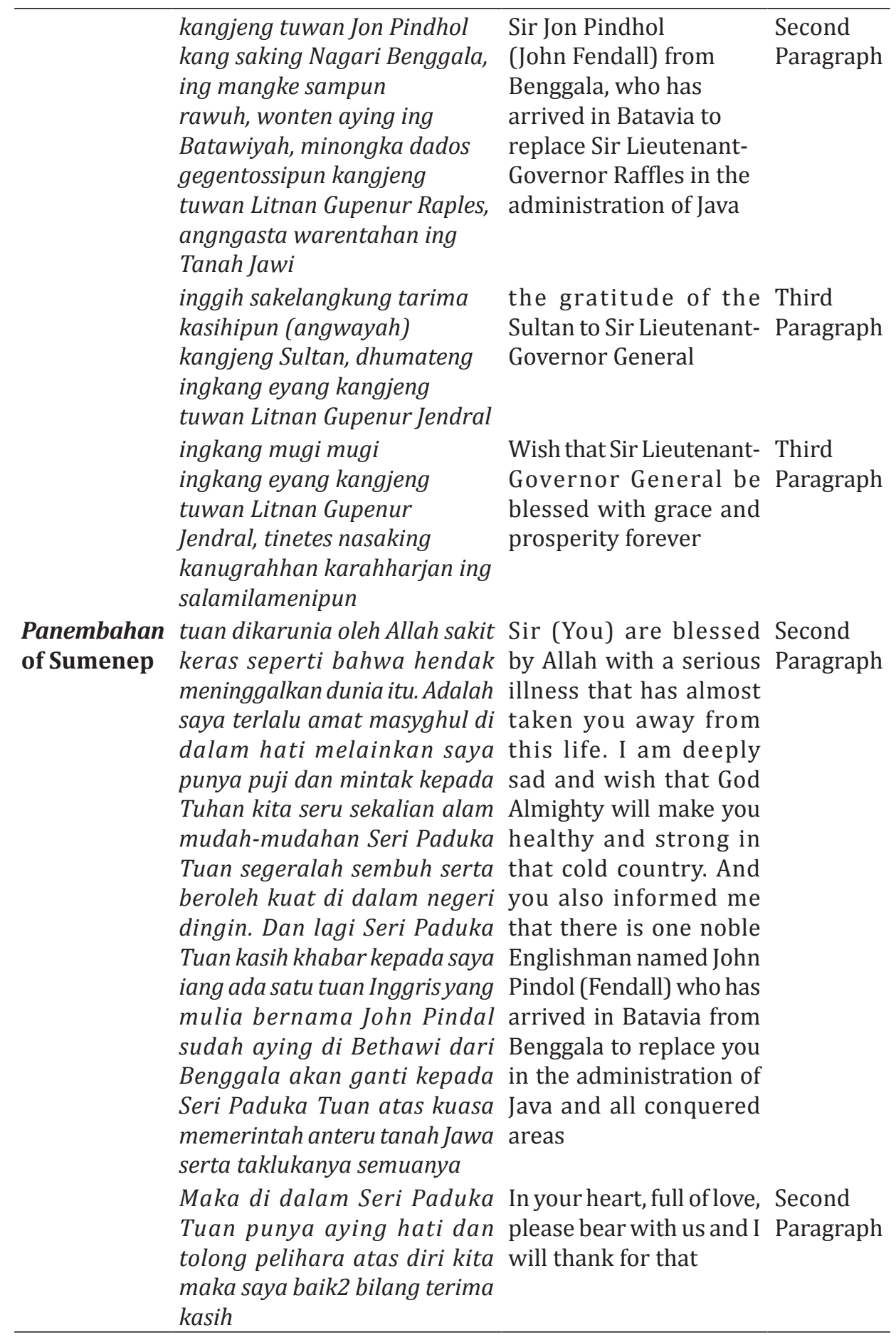




yang Seri Paduka Tuan baik Because of your love for Third
cinta pada saya apalagi sanak me and my family, we Paragraph
sahudara, kita semua serta Seri will all be friends forever
Paduka Tuan hendak sahabat
bersahabat selama2nya
Demikianlah kita punya mintak Thus, I hope Allah will Fourth
kepada Tuhan Allah mudah- forevermore make us Paragraph
mudahan mintakkan akan friends and bless us with
antara sahabat bersahabat love
dancintabercintaanyangtiada
berkeputusan selama2nya

(Source: Author's Compilation)

There are at least two main messages in both letters. Those are 'Raffles' illness' and 'John Fendall was sent to Java to replace him as a Lieutenant-Governor'. ${ }^{29}$ A slight difference is found in the tone of these two letters, with the letter from the Panembahan of Sumenep demonstrating that a more affectionate and special relationship has been built and intended to be preserved. As Wurtzburg notes, Raffles had a natural gift for making friends and an active interest in their history and customs, and as such he could easily form links between the chief European authorities and the native rulers and leave both with good impressions (1986, p. 379). Neither letter includes the words that usually conclude Malay letters, such as tamat or finis (Gallop, 1994, p. 77). However, both use words equivalent to 'forever' in their closings after making a good wish for the Lieutenant-Governor.

\section{Conclusion}

As noted in this paper's introduction, the Javanese language is somehow perceived by its native speakers as more cultured and aristocratic than the Malay language, which was the lingua France used for trade-especially in coastal area. From the above discussion, it can be briefly concluded that there are more similarities than differences

\footnotetext{
${ }^{29}$ Both topics are comprehensively covered in Chapter 18 by Wurtzburg (1986)
} 


\section{Gilang Maulana Majid}

between letters written in these languages, with letters written in Javanese trying to follow the common letter-writing practices of those written in Malay. This particular presents two interesting inferences. First, that the Malay language was not only influential throughout the Indonesian archipelago as a medium for verbal communication; even its letter-writing tradition seems to have affected its Javanese counterpart, setting a standard writing style for diplomatic letters. Second, this fact more or less contradicts the popular perception of the language itself. By adopting some of the norms of the terasul model, Javaneselanguage letters could communicate their messages in a fashion that was not unfamiliar to readers - in this case, Raffles. This could signify how diplomacy was conducted, and how different perceptions could actually be negotiated to attain certain goals.

From this point, it can be noted that historical research within the domain of social sciences in Indonesia still poses certain challenges, such as the relative lack of investigation into Javanese diplomatic letters than their Malay counterparts. Bearing the relevance of such studies in mind within the context of today's society, research into similar topics should be expanded in order to better understand the cultural richness of Indonesia. One can infer that, to some degree, a more established tradition - in this study, represented by the Malay letter-writing tradition - can in fact set an indirect consensus for the communication between rulers. Such hegemony can be highly relatable to any situation, even if applied to modern diplomatic relationships between countries. For instance, the many countries ratifying the United Nations Convention on Contracts for the International Sale of Goods (CISG) ${ }^{30}$ reflects an adaptation similar to the use of the Malay kitab terasul being adopted as the standard for Javanese letter-writing. As a suggestion for further research, a closer look on the letters from

\footnotetext{
${ }^{30}$ One reason behind Japan's accession to the CISG is the fact that many of its trade partners in Asia have joined, making the idea of having one common contract law more attractive than constant diversity (Sono, 2008, p. 110).
} 
the regents in Java sent to Raffles in the same context-addressing his retirement in 1816 - might prove fruitful, as these regents represented a lower level of governmental structure within the Javanese political sphere.

\section{Acknowledgements}

Many thanks to LPDP Scholarship (Indonesia Endowment Fund for Education) for the sponsorship and Jun. Prof. Dr. Elsa Clavé for the supervision.

\section{References}

Behrend, T. (2005). Frontispiece Architecture in Ngayograkarta: Notes on Structure and Sources. Archipel, Vol. 69, 39-60.

Dwiyanto, D. (2009). Kraton Yogyakarta: Sejarah, Nasionalisme \&

Teladan Perjuangan. Yogyakarta: Paradigma Indonesia.

Gallop, A. (2010). The Amuletic Cult of Ma'ruf Al-Karhi in the Malay World. Cambridge: Archetype. . (1994). The Legacy of the Malay Letter = Warisan Warkah

Melayu. London: British Library.

Gallop, A. \& Arps, B. (1991). Golden Letters: Writing Traditions of Indonesia. London \& Jakarta: British Library \& Yayasan Lontar.

Graaf, H. (2002). Puncak Kekuasaan Mataram: Politik Ekspansi Sultan Agung. Jakarta: Pustaka Utama Grafiti.

Graaf, H \& Pigeaud, T. (1985). Kerajaan-Kerajaan Islam Pertama di Jawa: Kajian Sejarah Politik Abad ke-15 dan ke-16. Jakarta: Grafiti Pers. Hannigan, T. (2011). When Raffles Ran Java. History Today. Vol. 61, No. 9, 10-17.

Hernawan, W. (2016). Menelusuri Para Raja Madura dari Masa PraIslam Hingga Masa Kolonial. Wawasan: Jurnal Ilmiah Agama dan Sosial Budaya Vol. 1, No. 2. DOI: http://dx.doi.org/10.15575/jw/ v1i2.589 


\section{Gilang Maulana Majid}

Kresna, A. (2011). Sejarah Panjang Mataram: Menengok Berdirinya Kesultanan Yogyakarta. Yogyakarta: DIVA Press.

Mangunsuwito, S. (2002a). Kamus Bahasa Jawa: Jawa-Indonesia. Bandung: Yrama Widya. . (2002b). Kamus Bahasa Jawa: Jawa-Jawa; Jawa-Indonesia; Indonesia-Jawa. Bandung: Yrama Widya.

Marihandono, D., \& Juwono, H. (2008). Sultan Hamengku Buwana II: Pembela Tradisi dan Kekuasaan Jawa. Yogyakarta: Banjar Aji Production.

Niel, R. (2005). Java's Northeast Coast, 1740-1840: A Study in Colonial Encroachment and Dominance. Leiden: CNWS Publications.

Pudjiastuti, T. (2005). Letters of the Sultans of Banten in the National Archives of the Republic of Indonesia. Sari, Vol. 23, 123-135.

Purwadi. (2008). History of Java: Melacak Asal-Usul Tanah Jawa. Yogyakarta: Mitra Abadi.

Rahayu, I. (2016). Pergeseran Kesultanan Sumenep ke Tangan VOC Tahun 1624-1705. Avatara, e-Journal Pendidikan Sejarah, Vol. 4, No. 3.

Ricklefs, M. (2008). A History of Modern Indonesia Since c. 1200. Fourth Edition. Stanford: Stanford University Press. (1993). War, Culture, and Economy in Java, 1677-1726: Asian and European Imperialism in the Early Kartasura Period. Sydney: Allen \& Unwin.

Ricklefs, M, Voorhoeve, P., \& Gallop, A. (2014). Indonesian Manuscripts in Great Britain. Jakarta: Yayasan Pustaka Obor Indonesia.

Sono, H. (2008). Japan's Accession to the CISG: The Asia Factor. Pace International Law Review, Vol. 20, Issue 1, 105-114.

Sudarmanto. (2008). Kamus Lengkap Bahasa Jawa (Jawa-Indonesia, Indonesia-Jawa). Semarang: Widya Karya.

Wurtzburg, C. (1986). Raffles of the Eastern Isles. Singapore: Oxford University Press. 


\section{Appendix 1: Transliteration of the Letter from the Sultan of Yogyakarta ${ }^{31}$}

Punika ingkang serat, pratondha tulus-iklas kawiyos ing manah suci ening remen ingkang temen-temen apawong-sanak, sarta ingkang tabee akathah-kathah, saking ingkang wayah kanjeng Sultan Hamengku Buwana Seenapati Ingalaga Ngabdurrahman Sayidin Panatagama Khalifatolah, ingkang kaping sekawan, ingkang anglenggani kedhaton negari ing Ngayogyakarta Hadiningrat, kahaturra ingkang Eeyang kangjeng tuwan ingkang ageng ingkang wiceksana, Tomas Tanporet Raples, Letnan-Gupenur ing pulo Jawi sabawahipun sadaya, ingkang anguwasani wadya-bala sarta prajurit Inggris, ingkang wonten ing tanah Jawi sabawahipun sadaya, saha pamujennipun ingkang wayah kangjeng Sultan saking eeklasing sing manah, ingkang mugi ingkang Eeyang kangjeng tuwan ingkang ageng ingkang wicaksana Litnan Gupenur Jendral, pinaossenna ingkang ingkang yusya salamet saha karahharjanne, denten ing dalem donya puniki.

Sasampuning kadya punika awiyos, ingkang wayah kangjeng Sultan ingkang sampun atampir serrat saking ingkang eyang kangjeng tuwan Litnan Gupenur Jenderal, saha sampun katumpik sanis raosing serrat sadhaya, ung ngeling sdarat, yen ingkang eyang kangjeng tuwan Litnan Gupenur Jendral, asukahuning ngadhateng ingkang wayah kangjeng Sultan, sareh ning kangjeng tuwan Litnan Gupenur, asangnget gerahipun, pramila akedhah angngupadhos panggennan ingkang sae payupang yen nan ingkang kenging kadamel tetirah amulyak nahinggesah, ing mangke ingkang panjenengngan badhe kdasahang leksasananni, dhumateng negari kap, sawontennipun ing ngriku sasetasis badhe lajeng dhumateng negari Inggris, kalih dening malih ingkang eyang kangjeng tuwan Litnan Gupenur, asukahuning ngamalih, dhumateng ingkang wayah kangjeng Sultan, yen anya menikala yan tata pranatan, ingkang sampun kadhamel Negari ing Ngiropa, kangjeng tuwan Jon Pindhol kang saking Nagari Benggala, ing mangke sampun rawuh, wonten negari ing Batawiyah, minongka

\footnotetext{
${ }^{31}$ I personally transcribed the letter from the Sultan of Yogyakarta as I was unable to find any sources that had already done so. The closest was the letter sent by Sultan Hamengku Buwana IV to Raffles in 1815 (Gallop, 1991, p. 141), which I utilized as my reference due to similarities in the letters' structures and some sentences. For instance, the complimentary section of both letters is the same. However, I acknowledge that my transcription may be imperfect, either due to my unfamiliarity with the words or due to the script being illegible.
} 


\section{Gilang Maulana Majid}

dados gegentossipun kangjeng tuwan litnan gupenur Raples, angngasta warentahan ing Tanah Jawi sarta sabawahipun sadaya kangjeng tuwan Litnan Gupenur, sampun angngandika dhumateng ingkang anggentossi, amer sabennaken ingkang wayah kangjeng Sultan, won dening kangjeng tuwan Litnan Gupenur, ingkang anyar anggennipun dhumateng ingkang wayah kangjeng Sultan, boten sumelang malih, hamas mika lulussaken, kadi dening ingkang sampun kalampahhan, ing nalika punika, kangjeng tuwan Litnan Gupenur ingnglair rakin pangngestonnipun, gennipunapa wong sanak, tuwinpangngocelli pundhateng ingkang wayah kangjeng Sultan, miwah dhateng ing sentana sentana putra sadaya, ing wusananipun mujennipun ingkang eyang kangjeng tuwan Litnan Gupenur, mugi ingkang wayah kangjeng Sultan, amanggiyasakangah ing kanugrahhan, kahiring nasakangah ing kabegan, karaharjan tuwin kusenengngan ngantos ing salami lamennipun, sarta kangjeng tuwan Litnan Gupenur, upami miring ngakangisening pamuji pahupunika, amesthihanda ngossaken sukapirennannipun ingkang galih.

Ingkang punika saroning ingkang eyang kangjeng tuwan Litnan Gupenur Jendral, asukahuningnga dhumateng ingkang wayah kangjeng Sultan, inggih sakelangkung tarima kasihipun (angwayah) kangjeng Sultan, dhumateng ingkang eyang kangjeng tuwan Litnan Gupenur Jendral, sareh sing ingkang eyang kangjeng tuwan Litnan Gupenur gerah sangnget, ingkang mugi gusti Allah aparing ngamulya, won dening ingkang eyang kangjeng tuwan Litnan Gupenur Jon Pindhol, sapunika sampun rawuh nigari ing Batawiyah. Menggah pengnganggepipun dhateng ingkang wayah kangjeng Sultan, boten sumelang malih, amesthi anglulussaken kadi dening ingkang sampun kalampahhan, ingkang punika inggih sakelangkung tarimakasihhipun, ingkang wayah kangjeng Sultan, menggah wiyanggeppipun ingkang wayah kangjeng Sultan, dhateng ingkang eyang kangjeng tuwan Litnan Gupenur Jon Pindhol, inggih sami ugi kadi dening pengnganggeppipun dhateng ingkang eyang kangjeng tuwan Litnan Gupenur Raples, kalih dening ingkang wayah kangjeng Sultan, ingngaturi hurmat selamet, satindakkipun ingkang eyang kangjeng tuwan Litnan Gupenur Jendral, dhateng negari ngekap, saha lajengngipun dhateng negari Inggris, saha pamujennipun ingkang wayah kangjeng Sultan, ingkang mugi mugi ingkang eyang kangjeng tuwan Litnan Gupenur Jendral, tinetes nasaking kanugrahhan karahharjan ing salamilamenipun.

Sinerrat ing Negari Ngayogyakarta Hadiningrat ing dinten ngahad tanggal pisanga sasi Jumadhilwal ing tahun Dal angkanning warsa 1743. 


\section{Appendix 2. Transliteration of the Letter from the Panembahan of Sumenep ${ }^{32}$}

Bahwa ini warkat ikhlas wa tuhfat al-ajnas yang terbit dari pada fuwad al-nur kita termaktub di dalamnya beberapa tabik dan hormat yang tiada berhingga pada tiap2 dan masa dan ketika serta melengkapi atasnya beberapa kebajikan dan kesentosaan yang senantiasa adanya selagi bumi langit keterangan dari pada cahaya peridaran cakrawala al-syams wa al-qamar, iaitu dari pada saya Panembahan Nata Kusuma yang di atas takhta kerajaan negeri Sumeneb, barang disampaikan Tuhan seru sekalian alam datang mengadap ke hadapan majlis sahabat kita yang dipermulia, iaitu Seri Paduka Honarabel Thomas Stamford Raffles yang ada bernaung di bawah takhta kerajaan maha besar negeri Ingglan, yang ia mukim lagi beristirahat al-khair di dalam negeri Ingglan. Maka dipohonkan pula atasnya beberapa kebajikan serta mintak dilanjutkan dari pada usyia umur zamannya ali al-dawam.

Wa-badahu kemudian dari pada itu maka adalah menerafakan nabzah yang s-n-r ini ke hadapan majlis Seri Paduka Tuan yang dipermulia dari pada menyatakan warkat al-ikhlas dari pada permulia itu telah sampailah kepada saya dengan selamat akmaliah adanya. Maka fahamlah dari pada barang yang terkandung di dalamnya yang Seri Paduka Tuan memberi tahu kepada saya yang tuan dikarunia oleh Allah sakit keras seperti bahwa hendak meninggalkan dunia itu. Adalah saya terlalu amat masyghul di dalam hati melainkan saya punya puji dan mintak kepada Tuhan kita seru sekalian alam mudahmudahan Seri Paduka Tuan segeralah sembuh serta beroleh kuat di dalam negeri dingin. Dan lagi Seri Padukan Tuan kasih khabar kepada saya iang ada satu tuan Inggris yang mulia bernama John Pindal sudah datang di Bethawi dari Benggala akan ganti kepada Seri Paduka Tuan atas kuasa memerintah anteru tanah Jawa serta taklukanya semuanya, iaitu turut bagaimana peraturan perintah negeri Ingglan. Ada pun dari hal saya ini sudahlah Seri Paduka Tuan membicarakan kepada yang ganti pada Seri Paduka Tuan atas kebajikan saya. Maka tinggal saya begitu juga bagaimana yang sudah2 saja tiada berubahkan melainkan tuan Lubtenan Gapernur yang baharu nanti juga bicarakan yang baik2 kepada Gapernament yang lagi hendak menggantikan pada Gapernament sekarang pada hal kebajikan dan kesenangan saya yang boleh dipeliharakan selama2nya. Maka

${ }^{32}$ The transcription of the letter from the Panembahan of Sumenep is taken from Gallop (1991, p. 138) 


\section{Gilang Maulana Majid}

di dalam Seri Paduka Tuan punya sayang hati dan tolong pelihara atas diri kita maka saya baik2 bilang terima kasih. Tiada boleh saya membalas akan yang demikian melainkan kita punya puji kepada tuan Allah mudah-mudahan mengurniai akan Seri Paduka Tuan beberapa kebajikan dan kesentosaan yang senantiasa di dalam dunia ini.

Syahdan lagi Seri Paduka Tuan membilang dengan sebenar2nya yang Seri Paduka Tuan baik cinta pada saya apalagi sanak sahudara, kita semua serta Seri Paduka Tuan hendak sahabat bersahabat selama2nya. Maka Seri Paduka Tuan mintak kepada Tuhan seru sekalian alam berilah saya tinggal baik dengan segala selamat serta mendapat kauntungan dan kesenangan. Jika besok Seri Paduka Tuan dapat khabar yang saya sudah dapat bahagian akan yang demikian niscayalah Seri Paduka Tuan baik suka hati yang tiada lagi tambahan. Maka apa yang telah tersebut di dalam nazam perkataan ini saya ada terlalu amat mengucap syukur kepada Tuhan kita seru sekalian alam yang Seri Paduka Tuan menunjukkan beberapa kecintaan atas diri saya.

Demikianlah kita punya mintak kepada Tuhan Allah mudahmudahan mintakkan akan antara sahabat bersahabat dan cinta bercintaan yang tiada berkeputusan selama2nya, melainkan saya kirim tabik dan segala hormat kepada Seri Paduka Tuan serta saya punya anak bini dan sanak sahudara semuanya ada membilang tabik dan hormat adanya. Hanya s-nya kita harap yang Tuhan Allah boleh jaga peliharakan Seri Paduka Tuan selama2nya jua adanya.

Tersurat di dalam negeri Sumeneb kepada tiga hari bulan Jumadilkir sanat 1231.

[Signature] [unclear] ... Nata Kusuma Panembahan Sumeneb 